\title{
ROSMARINUS OFFICINALIS ESSENTIAL OIL: ANTIPROLIFERATIVE, ANTIOXIDANT AND ANTIBACTERIAL ACTIVITIES
}

\section{Abdullah Ijaz Hussain ${ }^{1,4 *}$, Farooq Anwar ${ }^{2 *}$, Shahzad Ali Shahid Chatha ${ }^{1}$, Abdul Jabbar ${ }^{1}$, Shahid Mahboob ${ }^{3}$, Poonam Singh Nigam ${ }^{4}$}

${ }^{1}$ Department of Chemistry, Government College University, Faisalabad, Pakistan; ${ }^{2}$ Department of Chemistry and Biochemistry, University of Agriculture, Faisalabad, Pakistan; ${ }^{3}$ Department of Zoology, Government College University, Faisalabad, Pakistan; ${ }^{4}$ Centre of Molecular Biosciences, Institute of Biomedical Sciences Research, University of Ulster, Coleraine, BT52 1SA, UK.

\begin{abstract}
The aim of this work was to investigate and compare the antiproliferative, antioxidant and antibacterial activities of Rosmarinus officinalis essential oil, native to Pakistan. The essential oil content from the

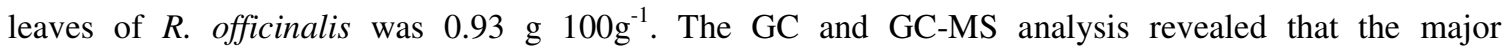
components determined in $R$. officinalis essential oil were 1,8-cineol (38.5\%), camphor (17.1\%), $\alpha$-pinene $(12.3 \%)$, limonene $(6.23 \%)$, camphene $(6.00 \%)$ and linalool $(5.70 \%)$. The antiproliferative activity was tested against two cancer (MCF-7 and LNCaP) and one fibroblast cell line (NIH-3T3) using the MTT assay, while, the antioxidant activity was evaluated by the reduction of 2, 2-diphenyl-1-picryl hydrazyl (DPPH) and measuring percent inhibition of peroxidation in linoleic acid system. The disc diffusion and modified resazurin microtitre-plate assays were used to evaluate the inhibition zones (IZ) and minimum inhibitory concentration (MIC) of $R$. officinalis essential oil, respectively. It is concluded from the results that Rosmarinus officinalis essential oil exhibited antiproliferative, antioxidant and antibacterial activities.
\end{abstract}

Key words: Antibacterial, Antioxidant, antiproliferative, 1,8-cienol, Resazurin assay

\section{INTRODUCTION}

Rosemary (Rosmarinus officinalis L.) is of considerable importance in term of its great an important medicinal and aromatic value. This plant belongs to Lamiaceae family. Rosemary is a perennial evergreen herb with fragrant needlelike leaves (2). Rosemary herbs have been widely used in the traditional medicine and cosmetics. They are also used as flavouring agents in foods (18). Rosmarinus officinalis essential oil is also important for its medicinal uses and its powerful antibacterial, cytotoxic, antimutagenic, antioxidant, antiphlogistic and chemopreventive properties $(4,12,17)$.
It is now evident that biological activities of the essential oils/extracts are correlated to the presence of specific chemical compounds $(5,4,8)$. The ecological conditions of different countries may influence the chemical profile of the plant materials, because some compounds may be accumulated at a particular period in response to environmental conditions (10, 11). Essential oils collected from different countries at different seasons comprise different chemical composition and thus may exhibit different biological activities (8). This prompted us to investigate the chemical profile of $R$. officinalis essential oil native to Pakistan and determine its biological activities.

There is no any detailed report available in the literature

*Corresponding Author. Mailing address: Department of Chemistry, GC University, Faisalabad-38000, Pakistan.; Tel.: 0092-41-9200066, ext 373.; E-mail: ai.hussain@yahoo.com / fqanwar@yahoo.com 
on the antiproliferative, antioxidant and antimicrobial activities of the $R$. officinalis essential oils from sub-continental region and in particular from Pakistan. In the present study, we investigated the chemical composition of the essential oil extracted from the leaves of $R$. officinalis native to Pakistan, and subsequently, their antiproliferative, antioxidant and antimicrobial potentials.

\section{MATERIAL AND METHODS}

\section{General}

The major equipment used was: GC (model-8700, PerkinElmer), GC/MS (6890N, Agilent-Technologies, California, USA), UV-VIS spectrophotometer (U-2001, model 121-0032 Hitachi, Tokyo, Japan) and Clevenger-type hydrodistillation apparatus. Butylated hydroxytoluene (BHT), linoleic acid, 2, 2,-diphenyl-1-picrylhydrazyl, dimethylsulfoxide, 3-[4,5dimethylthiazol-2,5-diphenyltetrazolium bromide] (MTT), homologous series of $\mathrm{C}_{9}-\mathrm{C}_{24} n$-alkanes and various reference chemicals used in this study were obtained from the Sigma Chemical Co. (St Louis, MO, USA). All other chemicals (analytical grade) i.e. ferrous chloride, ammonium thiocyanate, hydrochloric acid, chloroform, ethanol, and methanol used in this study were purchased from Merck (Darmstadt, Germany), unless stated otherwise. All culture media and standard antibiotic discs were purchased from Oxoid Ltd. (Hampshire, UK).

\section{Plant materials}

The leaves of Rosmarinus officinalis L. were collected from the Botanical Garden, University of Agriculture, Faisalabad, Pakistan during winter (November-December), 2007. The mean maximum and minimum temperature $\left({ }^{\circ} \mathrm{C}\right)$ for the months of November-December, 2007 in the University of Agriculture, Faisalabad region were: $28.6 \pm 6.7,15.0 \pm 3.5$ (average 21.8), respectively. The average relative humidity and total rainfall for the months of November-December 2007 in the University of Agriculture, Faisalabad region were $49.0 \pm$ $10.4 \%$ and $9.8 \mathrm{~mm}$, respectively. The plant specimens were further identified and authenticated by Dr. Mansoor Hameed, Taxonomist of the Department of Botany, University of Agriculture, Faisalabad, Pakistan. The specimen was further authenticated by comparison with an authentic voucher (No. 7087/13.4.34) of $R$. officinalis, deposited in the Herbarium of University of Agriculture, Faisalabad, Pakistan.

\section{Isolation of the essential oil}

The air-dried and finely ground (80 mesh) leaves of $R$. officinalis were hydro-distilled for $3 \mathrm{~h}$ using a Clevenger-type apparatus. Distillates of essential oil were collected and dried over anhydrous sodium sulfate, filtered and stored at $-4{ }^{\circ} \mathrm{C}$ until analyzed (8).

\section{Analysis of essential oil}

Gas chromatography analysis: The essential oil of $R$. officinalis was analyzed using a Perkin-Elmer gas chromatograph model 8700, fitted with a flame ionization detector (FID) and a HP-5MS capillary column (30 m x 0.25 $\mathrm{mm}$, film thickness $0.25 \mu \mathrm{m})$. The temperatures of the injector and detector were set at 220 and $290{ }^{\circ} \mathrm{C}$, respectively. The column oven temperature was programmed from $80{ }^{\circ} \mathrm{C}$ to 220 ${ }^{\circ} \mathrm{C}$ at a linear rate of $4{ }^{\circ} \mathrm{C} \mathrm{min}^{-1}$; initial and final temperatures were held for 3 and $10 \mathrm{~min}$, respectively. Helium was used as a carrier gas at the flow rate of $1.5 \mathrm{~mL} \mathrm{~min}^{-1}$. A $1.0 \mu \mathrm{L}$ sample was injected, using the split mode (split ratio, 1:100). All quantification was done by a built-in data-handling program provided by the manufacturer of the gas chromatograph (Perkin-Elmer, Norwalk, CT, USA). The composition was reported as a relative percentage of the total peak area. Furthermore, the major components $(>10 \%)$ were quantified by means of the internal standard addition method $(13,14)$.

Gas chromatography/mass spectrometry analysis: The essential oil were also analyzed by an Agilent-Technologies (Little Falls, California, USA) 6890N Network gas chromatographic (GC) system, equipped with an AgilentTechnologies 5975 inert XL Mass selective detector and Agilent-Technologies 7683B series auto-injector. Separation of 
the essential oil chemical constituents was carried out on HP-5 MS capillary column $(30 \mathrm{~m}$ x $0.25 \mathrm{~mm}$, film thickness 0.25 $\mu \mathrm{m}$; Little Falls, CA, USA). A $1.0 \mu \mathrm{L}$ sample volume was injected into the column using the split mode (split ratio 1:100). GC/MS detection was performed by an electron ionization system, with ionization energy of $70 \mathrm{eV}$. The column oven temperature program was the same as used previously in the GC analysis. The helium was used as carrier gas at a flow rate of $1.5 \mathrm{~mL} \mathrm{~min}^{-1}$. Mass scanning range was 50 $-550 \mathrm{~m} / \mathrm{z}$ while the injector and MS transfer line temperatures were set at 220 and $290{ }^{\circ} \mathrm{C}$, respectively.

Compounds identification: The essential oil components were identified on the basis of comparison of their mass spectra, retention times and retention indices with those of authentic samples and/or the NIST mass spectral library and the literature $(1,13,14,20)$.

\section{Antiproliferative activity}

Rosmarinus officinalis essential oil was solubilized in DMSO and then diluted in culture media for use. The human breast cancer (MCF-7) and fibroblast (NIH-3T3) cell-lines were maintained in Dulbecco's Minimum Essential Medium (DMEM), while hormone dependent prostate carcinoma LNCaP was cultured in RPMI 1640 medium. Both media were supplemented with $10 \%$ heat-inactivated fetal calf serum, $1 \%$ L-glutamine, $1 \%$ penicillin/streptomycin. Cells (10 $/$ well) were cultivated in 96 well plates for $24 \mathrm{~h}$ before the test compounds were added. Essential oils dilutions (10-500 $\left.\mu \mathrm{g} \mathrm{mL}^{-1}\right)$ were added to triplicate wells and cells were incubated for further 24 h. DMSO was tested as a solvent control while Doxorubicin as a reference standard. Cell viability was evaluated by the MTT assay and the percent inhibition of cell viability was calculated using cells treated with DMSO as control (15). The $\mathrm{IC}_{50}$ values (concentration at which $50 \%$ of cells were killed) were calculated.

\section{Antioxidant activity}

DPPH radical scavenging assay: The antioxidant activity of the essential oil was assessed by their ability to scavenging
2, 2'-diphenyl-1-picrylhydrazyl stable radicals (DPPH). The DPPH assay was performed as described by Mimica-Dukic et al. (14). The samples (from 10 to $500 \mu \mathrm{g} \mathrm{mL}^{-1}$ ) were mixed with $1 \mathrm{~mL}$ of $90 \mu \mathrm{M}$ DPPH solution and made up with $95 \%$ methanol, to a final volume of $4 \mathrm{~mL}$. Synthetic antioxidant, BHT was used as control. After $1 \mathrm{~h}$ incubation period at room temperature, the absorbance was recorded at $515 \mathrm{~nm}$. Percent radical scavenging concentration was calculated using the following formula:

$$
\text { Radical Scavenging }(\%)=100 \times\left(\mathrm{A}_{\text {blank }}-\mathrm{A}_{\text {sample }} / \mathrm{A}_{\text {blank }}\right)
$$

Where $A_{\text {blank }}$ is the absorbance of the control (containing all reagents except the test essential oil/compounds), and $\mathrm{A}_{\text {sample }}$ is the absorbance of the test essential oil/compounds. $\mathrm{IC}_{50}$ values, which represented the concentration of essential oil that caused $50 \%$ scavenging, were calculated from the plot of inhibition percentage against concentration.

\section{Percent inhibition in linoleic acid system: The} assessment of antioxidant activity of essential oil was also made in terms of percent inhibition of peroxidation in linoleic acid system following a reported method with slight modification (9). Essential oil (5 mg) were added to a solution mixture of linoleic acid $(0.13 \mathrm{~mL}), 99.8 \%$ ethanol $(10 \mathrm{~mL})$ and $10 \mathrm{~mL}$ of $0.2 \mathrm{M}$ sodium phosphate buffer ( $\mathrm{pH} 7$ ). Total mixture was diluted to $25 \mathrm{~mL}$ with distilled water. The solution was incubated at $40{ }^{\circ} \mathrm{C}$ for $175 \mathrm{~h}$. The extent of oxidation was measured by peroxide value colorimetrically. To $0.2 \mathrm{~mL}$ sample solution, $10 \mathrm{ml}$ of ethanol (75\%), $0.2 \mathrm{~mL}$ of an aqueous solution of ammonium thiocyanate $(30 \%)$ and $0.2 \mathrm{~mL}$ of ferrous chloride solution $(20 \mathrm{mM}$ in $3.5 \% \mathrm{HCl})$ were added sequentially. The mixture was stirred for $3 \mathrm{~min}$ and then absorbance recorded at 500nm. A control was performed with linoleic acid but without essential oil. Butylated hydroxytoluene (BHT) was used as a positive control. Percent inhibition of linoleic acid oxidation was calculated using the following equation:

Percent inhibition of linoleic acid oxidation $=100-[$ Abs. increase of sample at $175 \mathrm{~h} / \mathrm{Abs}$. increase of control at 175h) $\times$ 100] 


\section{Antibacterial activity}

The essential oil were tested against eight strains of bacteria: Staphylococcus aureus (NCTC 6571), Bacillus cereus (ATCC 11778), B. subtilis (NCTC 10400), Bacillus pumilis (wild type), Pseudomonas aeruginosa (NCTC 1662), Salmonella poona (NCTC 4840), Escherichia coli (ATCC 8739) and amphicilin resistant Escherichia coli (NCTC 10418). The bacterial strains were obtained from the Microbiology Laboratory, School of Biomedical Sciences, University of Ulster, Coleraine, Northern Ireland, UK. The strains were cultured overnight at $37^{\circ} \mathrm{C}$ in nutrient agar (NA, Oxoid).

Disc diffusion method: The antibacterial activity of the Rosmarinus officinalis essential oil was assessed by disc diffusion method (16). Briefly, $100 \mu \mathrm{L}$ of the suspension containing $10^{8}$ colony-forming units $(\mathrm{CFU}) / \mathrm{mL}$ of bacteria cells were spread on nutrient agar medium. The paper discs (6 $\mathrm{mm}$ in diameter) were separately impregnated with $15 \mu \mathrm{L}$ of essential oil or main components and placed on the agar which had previously been inoculated with the selected test microorganism. Ciprofloxacin $(25 \mu \mathrm{g} / \mathrm{dish})$ was used as a positive reference while the discs without samples were used as a negative control. Plates were kept at $4{ }^{\circ} \mathrm{C}$ for $1 \mathrm{~h}$ and then incubated at $37^{\circ} \mathrm{C}$ for $24 \mathrm{~h}$. Antibacterial activity was assessed by measuring the diameter of the growth-inhibition zone in millimeters (including disc diameter of $6 \mathrm{~mm}$ ) for the test organisms comparing to the controls.

Resazurin microtitre-plate assay: The minimum inhibitory concentration (MIC) of the essential oil was evaluated by a modified resazurin microtitre-plate assay as reported by Sarker et al. (19) with modification. Briefly, a volume of $100 \mu \mathrm{L}$ of $5.0 \mathrm{mg} \mathrm{mL}^{-1}$ (w/v) essential oil solutions in $10 \%$ dimethyl sulfoxide (DMSO, v/v) and $1 \mathrm{mg} \mathrm{mL} \mathrm{m}^{-1}$ of standard antibiotic in $10 \%$ DMSO was transferred into the first row of the 96 well plates. To all other wells, $50 \mu \mathrm{L}$ of nutrient broth were added. Two-fold serial dilutions were performed using a multichannel pipette such that each well had $50 \mu \mathrm{L}$ of the test material in serially descending concentrations. Thirty microliter of 3.3 time stronger isosensitised broth $(3.3 \mathrm{x})$ and $10 \mu \mathrm{L}$ of resazurin indicator solution (prepared by dissolving $270 \mathrm{mg}$ resazurin tablet in $40 \mathrm{~mL}$ of sterile distilled water) were added to each well. Finally, $10 \mu \mathrm{L}$ of bacterial suspension were added to each well to achieve a concentration of approx $5 \times 10^{5} \mathrm{cfu} / \mathrm{mL}$. Each plate was wrapped loosely with cling film to ensure that bacteria did not become dehydrated. Each plate had a set of controls: a column with a Ciprofloxacin as positive control, a column with all solutions with the exception of the test compound, a column with all solutions with the exception of the bacterial solution adding $10 \mu \mathrm{L}$ of nutrient broth instead and a column with 10\% DMSO (v/v) solution as a negative control. The plates were prepared in triplicate, and incubated at $37^{\circ} \mathrm{C}$ for $24 \mathrm{~h}$. The color change was then assessed visually. The growth was indicated by color changes from purple to pink or colorless. The lowest concentration at which color change appeared was taken as the MIC value.

\section{Statistical Analysis}

All the experiments were conducted in triplicate and the data are presented as mean values \pm standard deviation. Statistical analysis of the data was performed by Analysis of Variance (ANOVA) using STATISTICA 5.5 (Stat Soft Inc, Tulsa, OK, USA) software and a probability value of $p \leq 0.05$ was considered to denote a statistical significance difference among mean values.

\section{RESULTS AND DISCUSSION}

\section{Yield and composition of $R$. officinalis essential oil}

The oil content of Rosmarinus officinalis was found to be $0.93 \mathrm{~g} / 100 \mathrm{~g}$ (Table 1). The chemical components determined in the essential oils are given in Table 1. Eighteen compounds in the essential oil of $R$. officinalis, representing $97.42 \%$ of the oil, were identified (Figure 1). The major constituents (> 5\%) in the essential oil were found to be 1,8-cineol (38.5\%), camphor $(17.1 \%)$, $\alpha$-pinene $(12.3 \%)$, limonene $(6.23 \%)$, camphene $(6.00 \%)$, and linalool $(5.70 \%)$, respectively. In addition, the tested essential oil also contained considerable amounts of various minor constituents (Table 1). The amounts, 
calculated using calibrated curves with pure standards compounds, of the three main components, 1,8-cineol, camphor and $\alpha$-pinene, in the essential oil were found to be $37.1,15.8$ and $11.4 \mathrm{~g} / 100 \mathrm{~g}$ of oil (Table 1). As far as the groups of chemical constituents are concerned, the $R$. officinalis essential oil mainly consisted of oxygenated monoterpenes $(67.0 \%)$ followed by monoterpene hydrocarbons $(26.0 \%)$.

There are no previous data available in the literature on the quantitative $(\mathrm{g} / 100 \mathrm{~g})$ analysis of $R$. officinalis essential oil components with which our present results could be compared. However, there are some reports in the literature on the chemical composition of the different chemotypes of $R$. officinalis essential oil from different countries $(2,4,20)$. Little variation in the chemical compositions of $R$. officinalis essential oil across countries might be due to different ecological conditions. Our results are in agreement with the findings of Celiktas et al. (4), who also identified 1,8 cineol and $\alpha$-pinene as a major components of $R$. officinalis essential oil.

Table 1. Yield and chemical composition of Rosmarinus officinalis essential oil as identified by GC/MS analysis. ${ }^{\text {a }}$

\begin{tabular}{|c|c|c|c|c|}
\hline \multirow[t]{2}{*}{ Components $^{b}$} & \multirow[t]{2}{*}{$\mathbf{R I}^{\mathbf{c}}$} & \multicolumn{2}{|c|}{ Essential oil composition } & \multirow[t]{2}{*}{ Mode of identification $^{d}$} \\
\hline & & $\%$ & $\mathrm{~g} / \mathbf{1 0 0 g ^ { \mathrm { e } }}$ & \\
\hline Monoterpene hydrocarbons & & & & \\
\hline$\alpha$-pinene & 939 & $12.3 \pm 0.7$ & $11.4 \pm 0.3$ & RT, RI, MS \\
\hline camphene & 954 & $6.00 \pm 0.20$ & --- & RI, MS \\
\hline$\beta$-pinene & 979 & $0.20 \pm 0.27$ & --- & RT, RI, MS \\
\hline$\beta$-myrcene & 991 & $0.70 \pm 0.33$ & --- & RI, MS \\
\hline$\alpha$-phellandrene & 1003 & $0.15 \pm 0.03$ & --- & RI, MS \\
\hline limonene & 1029 & $6.23 \pm 0.31$ & --- & RT, RI, MS \\
\hline$\gamma$-terpinene & 1060 & $0.40 \pm 0.08$ & --- & RI, MS \\
\hline Oxygenated monoterpenes & & & & \\
\hline 1,8 -cineol & 1031 & $38.5 \pm 1.1$ & $37.1 \pm 1.1$ & RT, RI, MS \\
\hline linalool & 1097 & $5.70 \pm 0.22$ & --- & RT, RI, MS \\
\hline (+)-camphor & 1144 & $17.1 \pm 1.0$ & $15.8 \pm 0.5$ & RT, RI, MS \\
\hline isoborneol & 1156 & $0.20 \pm 0.02$ & --- & RI, MS \\
\hline borneol & 1169 & $3.25 \pm 0.15$ & --- & RT, RI, MS \\
\hline$\alpha$-terpineol & 1189 & $2.30 \pm 0.13$ & --- & RT, RI, MS \\
\hline Sesquiterpene hydrocarbons & & & & \\
\hline verbenone & 1207 & $1.11 \pm 0.04$ & --- & RI, MS \\
\hline$\beta$-caryophyllene & 1421 & $1.12 \pm 0.08$ & --- & RT, RI, MS \\
\hline$\beta$-farnesene & 1458 & $1.13 \pm 0.09$ & --- & RI, MS \\
\hline$\gamma$-muurolene & 1480 & $0.20 \pm 0.06$ & --- & RI, MS \\
\hline Oxygenated sesquiterpenes & & & & \\
\hline caryophyllene oxide & 1583 & $0.20 \pm 0.03$ & --- & RI, MS \\
\hline Others & & 0.63 & & \\
\hline tricyclene & 927 & $0.63 \pm 0.02$ & --- & RI, MS \\
\hline 3-octanone & 984 & --- & & RI, MS \\
\hline Total & & 97.42 & & \\
\hline Yield $(\mathrm{g} / 100 \mathrm{~g})$ & & 0.93 & & \\
\hline
\end{tabular}




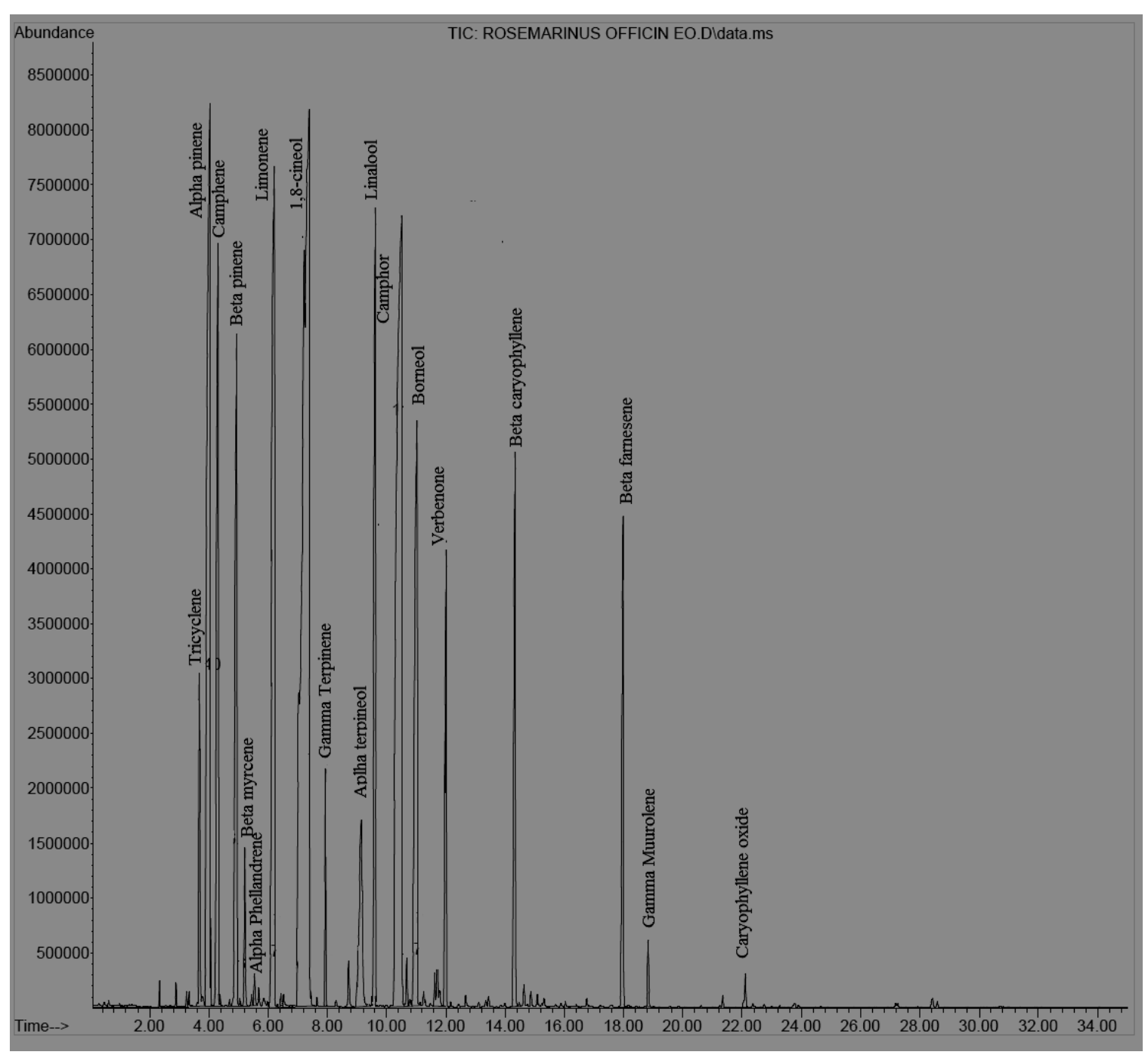

Figure 1. Typical GC-MS chromatograms of Rosmarinus officinalis essential oil showing the separations of chemical components.

\section{Biological activities}

Anti-proliferative activity: MTT assay, a sensitive, simple and reliable practice, which measured cell viability, was used to evaluate the anti-proliferative activity of $R$. officinalis essential oil. The effect of increasing amounts of $R$. officinalis essential oil on the cell proliferation of two human cancer (MCF-7 and LNCaP) and one fibroblast (NIH-3T3) cell lines was determined. The inhibitory effect of $R$. officinalis essential oil on cell viability ranged from $81-89 \%$ at $500 \mu \mathrm{g} \mathrm{mL} \mathrm{m}^{-1}$ (data not shown). The $\mathrm{IC}_{50}$ values, calculated from the graphs, are presented in Table 2, indicating that the essential oil showed the prominent anti-proliferative activity against both the cancer cell lines ( $\mathrm{IC}_{50} 190.1$ and $180.9 \mu \mathrm{g} \mathrm{mL} \mathrm{mL}^{-1}$, respectively). According to the published guidelines, the $\mathrm{IC}_{50}<10 \mu \mathrm{g} \mathrm{mL}$ represents potentially very toxic; $\mathrm{IC}_{50} 10-100 \mu \mathrm{g} / \mathrm{ml}$ represents potentially toxic; $\mathrm{IC}_{50} 100-1000 \mu \mathrm{g} / \mathrm{ml}$ represents potentially harmful, and $\mathrm{IC}_{50}>1000 \mu \mathrm{g} \mathrm{mL} \mathrm{m}^{-1}$ represents potentially nontoxic (6).

Antioxidant activity: The antioxidant activity of $R$. officinalis essential oil and the most abundant component were assessed by different in-vitro tests. In DPPH assay, the radical scavenging capacity of the tested essential oil increased in a concentration dependent manner. The values for $50 \%$ 
scavenging $\left(\mathrm{IC}_{50}\right)$ are given in Table 2. The essential oil showed better radical scavenging $\left(\mathrm{IC}_{50}: 20.9 \mu \mathrm{g} \mathrm{mL}^{-1}\right.$ ) than the main component of $R$. officinalis essential oil. Table 2 shows the level of percent inhibition of linoleic acid oxidation as exhibited by the tested essential oil. Again, the maximum inhibition was observed from $R$. officinalis essential oil (59.1 $\%$ ) while the main component of the oil showed poor activity (33.6\%). This might be due to the synergistic effect of some minor components present in the essential oil of $R$. officinalis.

Lipid peroxidation is a big issue in food industries and while comparing our results with the literature, we could not find a single report showing the percent inhibition of peroxidation by $R$. officinalis essential oil. However, there are some reports available in the recent literature on the radical scavenging activity of $R$. officinalis essential oil (3, 21). Our results are in close agreement with the findings of these reports.
Antibacterial activity: Rosmarinus officinalis essential oil exhibited varying antibacterial activity as is shown by the inhibition zones (IZ) and MIC values (Table 3). The results from the disc diffusion assay followed by modified resazurin assay indicated that the tested essential oil showed higher antibacterial activity against Gram-positive bacteria (IZ 18.024.2; MIC $0.20-0.48 \mathrm{mg} \mathrm{mL}^{-1}$ ) than against Gram-negative bacteria (IZ 12.8-17.5; MIC 1.16-1.72 $\mathrm{mg} \mathrm{mL}^{-1}$ ). It can be seen from Table 3 that $R$. officinalis essential oil exhibited better antibacterial activity than 1,8-cineol, a principal component of $R$. officinalis essential oil. There are also some reports in the literature on the antimicrobial activities of $R$. officinalis essential oil $(2,4,7)$ but the $R$. officinalis essential oil collected from Pakistan depicted better antibacterial activity as compare with these published reports. This might be due to little variation in the chemical profile of $R$. officinalis essential oil, native to Pakistan.

Table 2. Antiproliferative and antioxidant activities of Rosmarinus officinalis essential oil. ${ }^{\text {a }}$

\begin{tabular}{|c|c|c|c|c|}
\hline Parameters & Essential oil & 1,8-cineol & BHT & Doxorubicin \\
\hline \multicolumn{5}{|l|}{ Antiproliferative activity } \\
\hline $\mathrm{MCF}-7, \mathrm{IC}_{50}\left(\mu \mathrm{g} \mathrm{mL}^{-1}\right)$ & $190.1 \pm 6.0^{\mathrm{b}}$ & --- & --- & $28.8 \pm 1.2^{\mathrm{a}}$ \\
\hline $\mathrm{LNCaP}, \mathrm{IC}_{50}\left(\mu \mathrm{g} \mathrm{mL}^{-1}\right)$ & $180.9 \pm 4.5^{\mathrm{b}}$ & --- & --- & $33.3 \pm 1.1^{\mathrm{a}}$ \\
\hline Fibroblast (NIH-3T3) & $212.5 \pm 6.7$ & & & \\
\hline \multicolumn{5}{|l|}{ Antioxidant activity } \\
\hline $\mathrm{DPPH}, \mathrm{IC}_{50},\left(\mu \mathrm{g} \mathrm{mL}{ }^{-1}\right)$ & $20.9 \pm 0.9^{b}$ & $45.7 \pm 1.5^{\mathrm{c}}$ & $7.7 \pm 0.3^{\mathrm{a}}$ & --- \\
\hline Inhibition in linoleic acid system (\%) & $59.1 \pm 3.1^{\mathrm{b}}$ & $33.6 \pm 1.2^{\mathrm{a}}$ & $92.9 \pm 2.7^{\mathrm{c}}$ & --- \\
\hline
\end{tabular}

${ }^{a}$ Values are mean \pm standard deviation of three different samples of each Rosmarinus officinalis, analyzed individually in triplicate.

Means followed by different superscript letters in same row represent significant difference $(p<0.05)$.

Table 3. Antibacterial activity of the Rosmarinus officinalis essential oil. ${ }^{\mathrm{a}}$

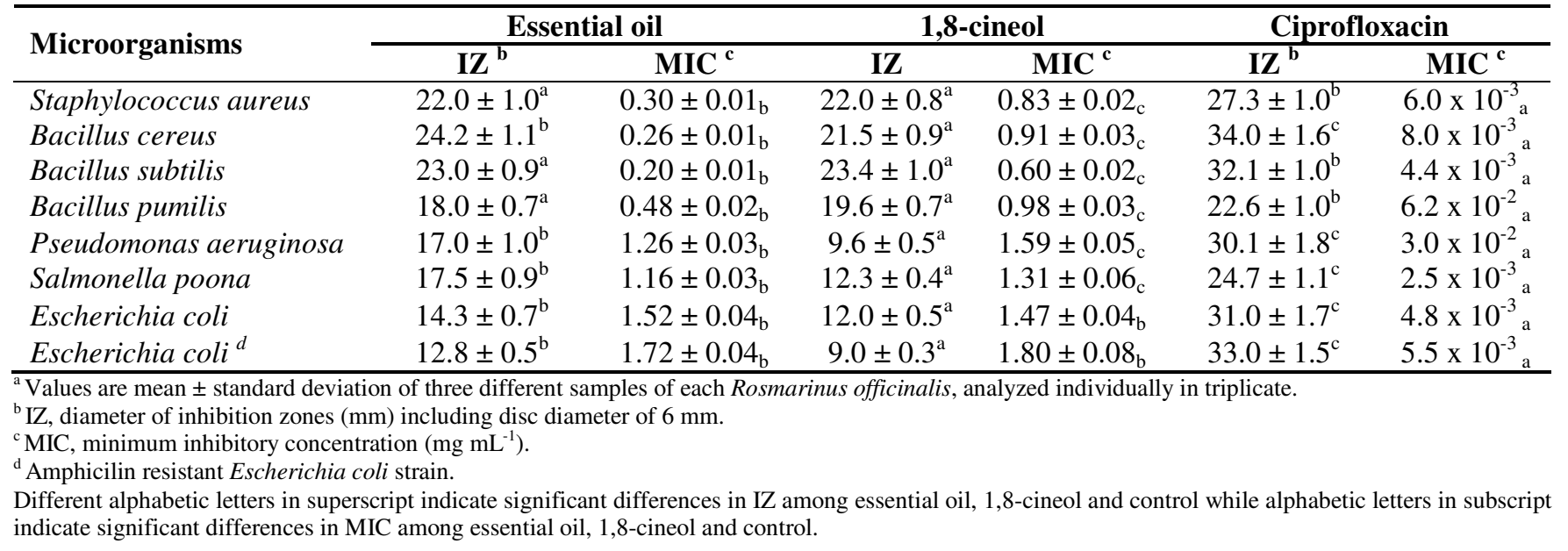




\section{CONCLUSION}

The results of the present study indicate that $R$. officinalis essential oil collected from Pakistan possessed very good antimicrobial and antiproliferative potentials as well as considerable antioxidant activity. A further study under the invivo conditions is recommended to further elaborate the antimicrobial and antioxidant principles of Rosmarinus officinalis essential oil for various useful applications. The investigated essential oil may be used for the preservation of processed foods as well as pharmaceutical and natural therapies for the treatment of infectious diseases in humans and plants.

\section{ACKNOWLEDGEMENTS}

We would like to extend our special gratitude to Professor M.I. Bhanger, Director, National Center of Excellence in Analytical Chemistry (NCEAC), University of Sindh, Jamshoro, Pakistan, for allowing us to use GC-MS instrumental facility. This work is a part of $\mathrm{PhD}$ project funded by the Higher Education Commision, Pakistan under the scheme of International Research Support Initiative Program (IRSIP) and Indigenous Ph.D. Fellowship Program.

\section{REFERENCES}

1. Adam, R.P. (2001). Identification of essential oil components by gas chromatography/quadrupole mass spectroscopy. Allured: Carol Stream, IL.

2. Bousbia, N.; Vian, M.A.; Ferhat, M.A.; Petitcolas, E.; Meklati, B.Y.; Chemat, F. (2008). Comparison of two isolation methods for essential oil from rosemary leaves: Hydrodistillation and microwave hydrodiffusion and gravity. Food Chem. 14, 355-362.

3. Bozin, B.; Mimica-Dukic, N.; Samojlik, I.; Jovin, E. (2007). Antimicrobial and antioxidant properties of rosmary and sage (Rosmarinus officinalis and Salvia officinalis, Lamiaceae) essential oils. J. Agric. Food Chem. 55, 7879-7885.

4. Celiktas, O.Y.; Kocabas, E.E.H.; Bedir, E.; Sukan, F.V.; Ozek, T.; Baser, K.H.C. (2007). Antimicrobial activities of methanol extracts and essential oils of Rosmarinus oficinalis, depending on location and seasonal variations. Food Chem. 100, 553-559.

5. Silva, A.B.; Silva, T.; Franco, E.S.; Rabelo, S.A.; Lima, E.R.; Mota,
R.A.; da Camara, C.A.G. Pontes-Filho, N.T.; Lima-Filho, J.V. (2010). Antibacterial activity, chemical composition, and cytotoxicity of leaf's essential oil from Brazilian pepper tree (Schinus terebinthifolius, Raddi) Braz. J. Microbiol. 41, 158-163.

6. Gad-Shayne, C. (1999). Alternatives to in vivo studies in toxicology. In: Balantyne B., Marrs T., Syversen T. (eds). General and applied toxicology, Vol (1). Grove's Dictionari's Inc., USA, p. 178.

7. Gachkar, L.; Yadegari, D.; Rezaei, M.B.; Taghizadeh, M.; Astaneh, S.A.; Rasooli, I. (2007). Chemical and biological characteristics of Cuminum cyminum and Rosmarinus officinalis essential oils. Food Chem. 102, 898904.

8. Hussain, A.I.; Anwar, F.; Sherazi, S.T.H.; Przybylski, R. (2008). Chemical composition, antioxidant and antimicrobial activities of basil (Ocimum basilicum) essential oils depends on seasonal variations. Food Chem. 108, 986-995.

9. Iqbal, S.; Bhanger, M.I.; Anwar, F. (2005). Antioxidant properties and components of some commercially available varieties of rice bran in Pakistan. Food Chem. 93, 265-272.

10. Kamatou, G.P.P.; Van-Zyl, R.L.; Van-Vuuren, S.F.; Figueiredo, A.C.; Barroso, J.G.; Pedro, L.G.; Viljoen, A.M. (2008). Seasonal variation in essential oil composition, oil toxicity and the biological activity of solvent extracts of three South African Salvia species. South African J. Bot. 74, 230-237.

11. Koenen, E.V. (2001). Medicinal poisonous and edible plants in Namibia. Klaus Hess Publishers, Verlag, Berlin.

12. Koschier, E.H.; Sedy, K.A. (2003). Labiate essential oils affecting host selection and acceptance of Thrips, Tabaci lindeman. Crop Prot. 22, 929-934.

13. Massada, Y. (1976). Analysis of essential oils by gas chromatography and mass spectrometery. John Wiley \& Sons, New York.

14. Mimica-Dukic N.; Bozin, B.; Sokovic, M.; Mihajlovic, B.; Matavulj, M. (2003). Antimicrobial and antioxidant activities of three Mentha species essential oils. Planta Medica 69, 413-419.

15. Mosmann, T. (1983). Rapid colorimetric assay or cellular growth and survival: application to proliferation and cytotoxicity assays. J. Immunol Meth. 65, 55-63.

16. NCCLS (National Committee for Clinical laboratory Standards). (1997). Performance standards for antimicrobial disc susceptibility test $\left(6^{\text {th }}\right.$ ed.) approved Standard. M2-A6, Wayne, PA.

17. Ohno, T.; Kita, M.; Yamaoka, Y.; Imamura, S.; Yamamoto, T.; Mitsufuji, S.; Kodama, T.; Kashima, K.; Imanishi, J. (2003). Antimicrobial activity of essential oils against Helicobacter pylori. Helicobacter 8, 207-215.

18. Pintore, G.; Usai, M.; Bradesi, P.; Juliano, C.; Boatto, G.; Tomi, F.; Chessa, M.; Cerri, R.; Casanova, J. (2002). Chemical composition and antimicrobial activity of Rosmarinus officinalis L. oils from Sardinia and Corsica. Flav. Frag. J. 17, 15-19.

19. Sarker, S.D.; Nahar, L.; Kumarasamy, Y. (2007). Microtitre plate-based antibacterial assay incorporating resazurin as an indicator of cell growth, 
Hussain, A.I. et al.

and its application in the in vitro antibacterial screening of phytochemicals. Methods 42, 321-324.

20. Vagionas, K.; Graikou, K.; Ngassapa, O.; Runyoro, D.; Chinou, I. (2007). Composition and antimicrobial activity of the essential oils of three
R. officinalis essential oil: antibacterial activities

Satureja species growing in Tanzania. Food Chem. 103, 319-324.

21. Wang, W.; Wu, N.; Zu, Y.G.; Fu, Y.J. (2008). Antioxidant activity of Rosmarinus officinalis L. essential oil compared to its main components. Food Chem. 108, 1019-1022. 